\title{
SuIndiWeb: A Web-Based Platform of Sutte Indicator Predicting Movement of Stock
}

\author{
Ansari Saleh Ahmar \\ Universitas Negeri Makassar \\ Makassar, Indonesia \\ ansarisaleh@unm.ac.id
}

\begin{abstract}
Technical Indicator is one of approach to analyze the movement of stock. Will this stock decrease or increase in future? One new measurement that has been developed is Sutte Indicator. The Sutte Indicator is an indicator used in Technical Analysis of Stock Market. Sutte Indicator helps in the decision making process for stock investors when they can make a buy or sale of stocks. Sutte Indicator has been implemented in several stocks suchas Apple Inc., XL AxiataTbk and Smartfren Telecom Tbk. To view the reliability in the prediction of SutteIndicator then it has been compared with other Technical Analysis such as Simple Moving Average (SMA) and Moving Average Convergence/Divergence (MACD). From the results of this comparison, The obtained result showed that this indicator has a better level of accuracy than the SMA and MACD. To simplify the implementation process of Sutte Indicator, a tool on Webbased platform has been made and named as SuIndiWeb. Thus, SuIndiWeb can be utilized in the process of predicting stock movements.
\end{abstract}

Keywords—sutte indicator; SuIndiWeb; web based; predicting; movement; stock

\section{INTRODUCTION}

There is an improvement in the trading system in Indonesia. If we look backward, we can see that the trading system has been improved because of the use of technology especially the information technology. This improvement also attracted more people who are intended to seek more valuable commodity and monetary value not only in real market but also in the trading market or stock trading market. Moreover, the improvement of the technology also creates more applicable application to understand the movement of the stock exchange system.

Stock trading in Indonesia is an activity that requires precision and foresight in seeing the stock movement. The movement of stock prices in the stock market is not volatile and are not bound by time, sometimes rising, sometimes down, and not infrequently also constant. The movement of stock is called the fluctuations. Stock trading is one of transaction that is interesting by investors. As presented by Media Online Republika at 28 Oktober 2016 state that the Indonesia Stock Exchange (IDX) recorded the number of stock investors in Indonesia until February 2016 until 468 thousand people. This figure increased by 8 percent if compared to the position at the end of 2015, with improved movement of Stock Price Index (IHSG) that ranks second in the world. To get the maximum profit in stock trading, then an investor must predict stock movements using technical analysis. In the flow of stocks, there are five main of components necessary to chart the movement of stocks that can be formed. The five main components are opening price, highest price, lowest price, closing price, and the volume of transactions [1], [2].Technical analysis has been described by many researchers, including Stochastic, MACD and Bollinger bands [3], Moving Avarage [4], dan Relative Strength Index (RSI) [5], and the latest technical analysis developed is Sutte Indicator [1], [2].

The technical analysis have been used by Zhu and Zhou to study the usefulness of moving the average [6]. Moreover, McKenzie tested the rules of technical trading for 17 markets of selected developing countries and concluded that there was no regular trading rules that can generate sufficient forecasting accuracy [7].

Sutte Indicator is a technical analysis which was developed by considering four main of components of the stock movements. They are then illustrated in a graph stock movements. The formula of Sutte Indicators [1], [2]:

$$
\begin{aligned}
& {\left[\text { SUTTE } \% \mathrm{~L}=\left(\frac{\mathrm{C}_{\mathrm{k}}+C_{k-1}}{2}\right)+\mathrm{C}_{\mathrm{k}}-\mathrm{L}_{\mathrm{k}}\right]} \\
& \text { SUTTE } \% \mathrm{H}=\left(\frac{\mathrm{C}_{\mathrm{k}}+C_{k-1}}{2}\right)+\mathrm{H}_{\mathrm{k}}-\mathrm{C}_{\mathrm{k}}
\end{aligned}
$$

$$
\text { SUTTE- PRED }=\frac{\text { SUTTE } \% \text { L }+ \text { SUTTE } \% H}{2}
$$

Where :

$\begin{array}{ll}C_{k} & =\text { closing price of stock at } k^{\text {th }} \text {-day } \\ C_{k-1} & =\text { closing price of stock at } k-1^{\text {th }} \text { day } \\ L_{k} & =\text { lowest price of stock at } k^{\text {th }} \text {-day } \\ H_{k} & =\text { highest price of stock at } k^{\text {th }} \text {-day } \\ \text { SUTTE\%L } & =\text { limit of lowest prices of Sutte Indicator } \\ \text { SUTTE\%H } & =\text { limit of highest price of Sutte Indicator }\end{array}$


Sutte-Pred $=$ prediction price of stock using Sutte Indicator.

In order to make it easy to be utilized in the decisionmaking process, Sutte Indicator should be readily available and easy to use. Recently, many users more frequently use the Internet as a media because it is easily accessible. Based on the survey conducted by the Association of Indonesian Internet Network Operator (APJII) during the year 2016, it is said that 132,7 million people of Indonesia has been connected to the internet from a total population of 256.2 million inhabitants. Furthermore, Ahmar, Rusli, \& Rahman adds that the technology is applied properly will reduce the pathways work process step procedure, which was performed manually will be replaced by the system [8]. Beneficiaries of such technology is the basis for applied of management information system (MIS).

\section{DESIGN OF SYSTEM}

The Sutte indicator is developed by the working of a webbased application[1]. The worke flow of this web can be seen in figure below.

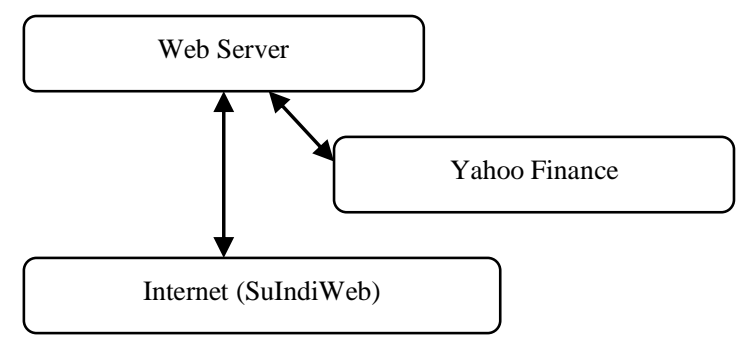

Fig. 1. Worked Flow of SuIndiWeb.

From the figure above, we can see that stock price movements of SuIndiWeb by using Sutte Indicators can be done by using the internet. The process of getting the stock price data can be accessed from Yahoo Finance. The downloaded Stock data are the data about the opening price, the highest price, the lowest price, and the closing price which will be implemented into the Sutte Indicator formula.

SuIndiWeb developed using Web programming (Code Igniter) and MySQL database [8]. As for the graphics used Fushion Chart plugin for the internet.

The instruments that were used in this research are several database of stock exchange and they were analysed by using the web programming database systems. This system was look at the dynamic system through the time base and the movement of the market price of the stock.

\section{RESULT AND DISCUSSION}

From the results of design that has been done, then the following results from database of SuIndiWeb.
TABLE I. STOCKTABLE

\begin{tabular}{|l|l|l|}
\hline \multicolumn{1}{|c|}{ Field } & \multicolumn{1}{|c|}{ Type } & Length \\
\hline id & Int & 11 \\
date & Varchar & 200 \\
open & Double & 0 \\
high & Double & 0 \\
low & Double & 0 \\
close & Double & 0 \\
volume & Double & 0 \\
adjclose & Double & 0 \\
label & Varchar & 200 \\
\hline
\end{tabular}

Table stock created to save data results from Yahoo Finance and name of stock will be recorded in the field label.

TABLE II. SUTTETABLE

\begin{tabular}{|c|c|c|}
\hline Field & Type & Length \\
\hline id & Int & 11 \\
date & varchar & 200 \\
close & double & 0 \\
sutL & double & 0 \\
sutH & double & 0 \\
pred & double & 0 \\
label & varchar & 200 \\
label & varchar & 200 \\
\hline
\end{tabular}

Sutte table is used to store the results of data analysis using Sutte Indicator. From Sutte table, we make value of predicting and put them into a chart of stock movements.

In the trial stage, the stock used is Facebook Inc. The chart of this stock using a Web-based Sutte Indicator (SuIndiWeb) is shown in the following figure.

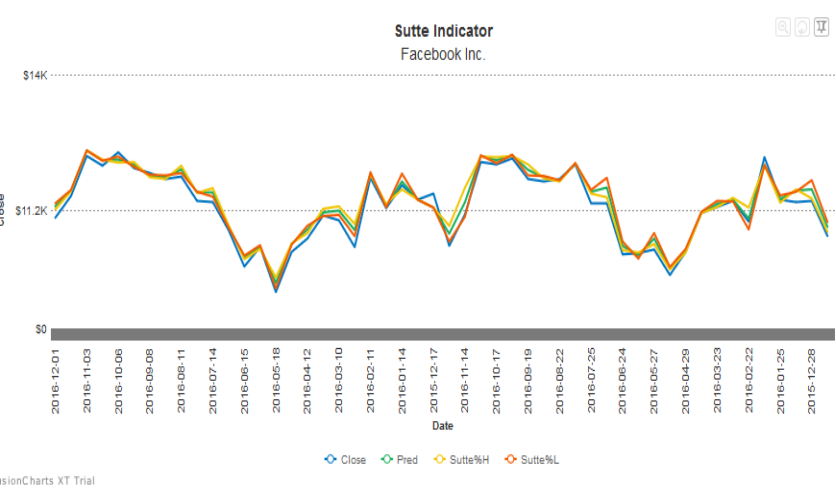

Fig. 2. Graph of Facebook Inc. on SuIndiWeb.

SUTTE indicator also has three types of predictive, namely SUTTE\%L, SUTTE\%H, and SUTTE-Pred. These three indicators are supporting each other to provide a picture of the movement of stocks. In giving the motion image of stocks, SUTTE link between SUTTE\%L and SUTTE\%H. If the curve SUTTE\%L is above of the curve SUTTE\% $\mathrm{H}$ in an extended period of time then it indicates that the stock price will 
increase and vice versa. If the curve of SUTTE\%H is above of the curve of SUTTE\%L then the stock price will decline. Increases and decreases processes in stock prices are usually marked by the intersection of the curve SUTTE\%L and SUTTE\%H.

From Figure 2 above, it shows that SuIndiWeb are in accordance with the criteria established by Sutte Indicator this means that SuIndiWeb can be used as a tool to predict movement of stock price by using Sutte Indicator.

\section{CONCLUSION}

Development of web-based decision-making is ideal to favor of making a decision. SuIndiWeb is a web-based decision-making system. By considering the figure and chart, it can be said that SuIndiWeb is a tool that can be used in predicting stock prices using Sutte Indicator.

\section{REFERENCES}

[1] A. S. Ahmar, "Sutte Indicator," 2015.

[2] A. S. Ahmar, "Sutte Indicator: A Technical Indicator in Stock Market," Int. J. Econ. Financ. Issues, vol. 7, no. 2, 2017.

[3] J. Nithya and G. Thamizhchelvan, "Effectiveness of Technical Analysis in Banking Sector of Equity Market," IOSR J. Bus. Manag., vol. 16, no. 7, pp. 20-28, 2014.

[4] Y. Han, K. Yang, and G. Zhou, "A New Anomaly: The Cross-Sectional Profitability of Technical Analysis," J. Financ. Quant. Anal., vol. 48, no. 5, pp. 1433-1461, 2013.

[5] B. S. Abbey and J. A. Doukas, "Is Technical Analysis Profitable for Individual Currency Traders," J. Portf. Manag., vol. 1, no. 910, pp. 142150, 2012.

[6] Y. Zhu and G. Zhou, "Technical analysis: An asset allocation perspective on the use of moving averages," J. financ. econ., vol. 92, no. 3, pp. 519-544, 2009

[7] M. McKenzie, "Technical Trading Rules in Emerging Markets and the 1997 Asian Currency Crises," Emerg. Mark. Financ. Trade, vol. 43, no. 4, pp. 46-73, Aug. 2007.

[8] A. S. Ahmar, Rusli, and A. Rahman, "Steps in Designing Queue and Interview Process using Information System: A Case of Re-registration of New Students in Universitas Negeri Makassar," Asian J. Technol. Manag., vol. 9, no. 1, pp. 52-57, 2016. 